\title{
Analysis of the 5S RNA Pool in Arabidopsis thaliana: RNAs Are Heterogeneous and Only Two of the Genomic 5S Loci Produce Mature 5S RNA
}

\author{
Catherine Cloix, ${ }^{1}$ Sylvie Tutois, ${ }^{1}$ Yasushi Yukawa, ${ }^{2}$ Olivier Mathieu, ${ }^{1}$ \\ Claudine Cuvillier, ${ }^{1}$ Marie-Claude Espagnol, ${ }^{1}$ Georges Picard, ${ }^{1}$ and \\ Sylvette Tourmente ${ }^{1,3}$ \\ ${ }^{1}$ U.M.R. 6547 BIOMOVE, Université Blaise Pascal, 24 Avenue des Landais, 63177 Aubière Cedex, France; ${ }^{2}$ Center for Gene \\ Research, Nagoya University, Nagoya 464-8602, Japan
}

\begin{abstract}
One major 5S RNA, 120 bases long, was revealed by an analysis of mature 5S RNA from tissues, developmental stages, and polysomes in Arabidopsis thaliana. Minor 5S RNA were also found, varying from the major one by one or two base substitutions; 5S rDNA units from each $5 \mathrm{~S}$ array of the Arabidopsis genome were isolated by PCR using CIC yeast artificial chromosomes (YACs) mapped on the different loci. By using a comparison of the $5 \mathrm{~S}$ DNA and RNA sequences, we could show that both major and minor $5 S$ transcripts come from only two of the genomic 5 S loci: chromosome 4 and chromosome 5 major block. Other $5 \mathrm{~S}$ loci are either not transcribed or produce rapidly degraded $5 S$ transcripts. Analysis of the 5'-and 3 '-DNA flanking sequence has permitted the definition of specific signatures for each 5S rDNA array.
\end{abstract}

[EMBL accession nos: AF330825-AF331032; AF335777-AF335873.]

The 5S rDNA in higher eukaryotes is generally organized in tandem arrays, the repeating unit of which contains the transcription unit and a spacer sequence. These tandem arrays may be localized on one or several chromosomes and are separated from the genes encoding the large rRNAs (Long and Dawid, 1980; Appels et al. 1980; Ellis et al. 1988). It is assumed that only a few highly homologous $5 \mathrm{~S}$ genes are transcriptionally active, whereas the majority of potentially active genes remain silent (Fulnecek et al. 1998). However, it is not known which specific 5S rDNA units are transcribed.

Heterogeneity of 5S RNA transcripts has been reported for a wide range of organisms including bacteria (Jarry and Rosset, 1971), fungi (Wildeman and Nazar, 1982; Chen et al. 1984), echinoderms (Lu et al. 1980), arthropods (Komiya et al. 1980), amphibia (Ford and Southern, 1973), birds, and mammals (Ro-Choi et al. 1971). Furthermore, in Escherichia coli, Xenopus, and Neurospora it is known that heterogeneous $5 \mathrm{~S}$ RNA exist in ribosomes. In Escherichia coli and Neurospora, the biological impact of 5S RNA heterogeneity is unknown. In Xenopus, a well-characterized model, there is a developmental regulation of expression for the two families of $5 \mathrm{~S}$ rRNA (Peterson et al. 1980). O'Brien and Wolin (1994) have shown that the Ro protein binds specifically some mutant 5S RNA, and this protein has been proposed to function in a quality control or discard pathway for 5S rRNA synthesis in Xenopus oocytes (Shi et al. 1996)

In the plant kingdom, accumulated data show that $5 \mathrm{~S}$ rRNA genes are highly conserved with respect to both length

\footnotetext{
${ }^{3}$ Corresponding author.
}

E MAIL Sylvette.TOURMENTE@geem.univ-bpclermont.fr; FAX (33) 473407777 .

Article published on-line before print in December 2001: Genome Res., 10.1101/gr.181302.

Article and publication are at http://www.genome.org/cgi/doi/10.1101/ gr.181301. and nucleotide sequence, whereas the intergenic spacers evolve more rapidly. 5S rDNA gene variants have been described in several plant species, such as sugar beet (Schmidt et al., 1994), sea barley (Baum and Johnson, 1998), wheat, rye (Campenhout et al., 1998), pea (Ellis et al., 1988), and flax (Schneeberger et al., 1989; Agarwal et al., 1992), and gymnosperms such as Larch and Pinaceae (Trontin et al. 1999). One example of $5 \mathrm{~S}$ transcript heterogeneity has been reported in rice embryos (Hariharan et al. 1987).

Arabidopsis thaliana is known to contain $\sim 1000$ copies of $5 \mathrm{~S}$ rDNA per haploid genome, and these occur in tandem arrays (Campell et al., 1992) localized in the pericentromeric heterochromatin of chromosomes 3, 4, and 5 (with a major locus on the left arm and a minor locus on the right arm of chromosome 5) in the Columbia ecotype (Murata et al. 1997; Fransz et al. 1998). In Arabidopsis thaliana, two types of 5S rDNA repeated units exist: the major variant with $0.5-\mathrm{kb}$ repeats and one with short repeats $(251 \mathrm{bp})$. The 121-bp transcribed sequence is highly conserved, whereas the intergenic spacer shows a high polymorphism for both length and nucleotide sequence. Although 5S rDNA sequences displayed noticeable heterogeneity, we were able to group them according to the 5 S loci (Cloix et al. 2000).

We report here an analysis of the 5S RNA pool in Arabidopsis thaliana (Columbia ecotype). Both major and minor $5 \mathrm{~S}$ RNA transcripts are produced in all the tissues and developmental stages analyzed. The specific $5 \mathrm{~S}$ rDNA units producing these transcripts have been identified, most of them belonging to the same $5 \mathrm{~S}$ block. Some $5 \mathrm{~S}$ arrays have been shown to be either silent or producing 5S RNA that is rapidly degraded. 5S RNA from these blocks were also not detected using an in vitro transcription system. 5S RNA heterogeneity has also been shown in ribosomes. Furthermore, analysis of the $5^{\prime}$ and 3' DNA flanking sequences has permitted the definition of specific signatures for each $5 \mathrm{~S}$ block. 


\section{RESULTS}

The Arabidopsis thaliana Columbia ecotype possesses 5S rDNA loci in the pericentromeric region of chromosomes 3, 4, and 5 (Murata et al. 1997; Camilleri et al. 1998; Fransz et al. 1998; Schmidt et al. 1995; Tutois et al. 1999 and Fig. 1) for a total of $\sim 1000$ 5S rDNA genes. The genome of $A$. thaliana has been sequenced (Arabidopsis Genome Initiative, 2000a), and physical maps using bacterial artificial chromosomes (BACs), transformation-competent artificial chromosomes (TACs), phage $\mathrm{P} 1$, and cosmids realized for each chromosome. 5S rDNA loci have been mapped using BACs on chromosome 3 (AGI, 2000b), YACs on chromosome 4 (Schmidt et al., 1995), YACs on the chromosome 5 left arm (Tutois et al. 1999), and BACs on the chromosome 5 right arm (Kotani et al. 1999; AGI, 2000c).

We have integrated these physical mapping, sequence, and restriction polymorphism results (papers cited above and Cloix et al. 2000) leading to a BACs/CIC (CNRS, INRA, CEPH) YACs/5S loci correspondence presented in Figure 1: chromosome 3: YAC 9A5/BAC F4M19 (5SrDNA1), YAC 7E7/BAC T18B3 (5SrDNA2), YAC 7G3/BAC T28G19 (5SrDNA3); chromosome 4: YACs 9D3-5C3-7H3; chromosome 5 major block: YACs 6A1-4E4; and chromosome 5 minor block: YAC11 A3/ BAC T25B21.

\section{S rRNA: 1 Major Transcript}

To investigate the 5S RNA population, we isolated total RNA from four different tissues (leaves, flowers, stems, and siliques) and from five different stages of development $(2-, 4-, 6-, 10-$ and 16-d-old plants). RT-PCR experiments were performed on RNAs using oligonucleotides RT 1 and RT 2 (Fig. 2A). This set of primers was chosen using the transcribed region defined by Campell et al. (1992) and the consensus sequence of each 5S locus (Cloix et al. 2000). Primers are not degenerate because very low variability was observed in the transcribed region (Cloix et al. 2000). Consequently, all sequences obtained by PCR are identical in the regions covered by the primers, that is, 1 to 18 and 103 to 121 (Fig. $2 \mathrm{~A}$ ).

A total of 308 RT-PCR products of these different tissues and developmental stages were sequenced. One major transcript was observed in 254 of 308 (82\%) sequenced 5S RNA

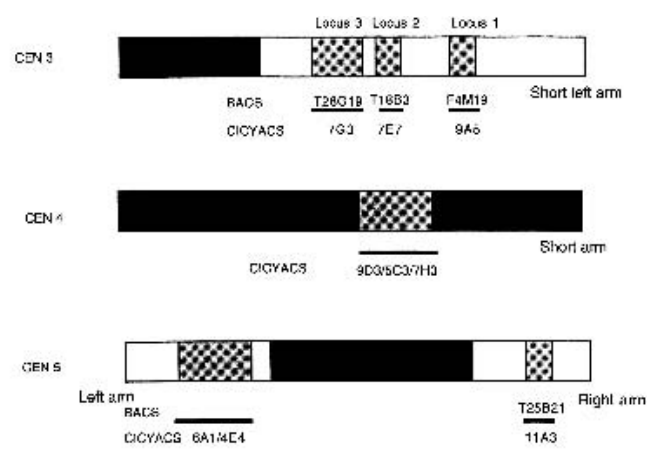

Controntric - repeats $180 \mathrm{tp}$

$\because \%$ 5s rova arreys

Figure 1 Karyotype of Arabidopsis thaliana Columbia ecotype showing the loci of the $5 \mathrm{~S}$ rDNA arrays in the pericentromeric regions of chromosomes 3, 4, and 5. The corresponding mapped CIC YACs and BACs for each $5 \mathrm{~S}$ locus are presented. transcripts, the sequence of which is given in Figure 3. At early developmental stages, that is, 2 and $4 \mathrm{~d}$ after germination, the percentage of the major transcript decreased to $75 \%$. In addition to this major transcript, 44 different sequenced products were identified as minor transcripts. They vary from the major one almost always by one or two single base substitutions.

To exclude RT-PCR errors, only minor transcripts found several times in tissue and/or developmental stages and/or found in polysomes (see below) are presented, giving a total of 15. Eight of the minor transcripts identified several times in the tissues or in developmental stages are aligned with the $5 \mathrm{~S}$ major transcript in Figure 3 (lanes 1-8 and the seven remaining are presented below). The minor transcripts are named with the position of the residue modified. Their provenances are indicated to the right of the alignment (Fig. 3, first column). Thus, one major transcript is present in the Arabidopsis Columbia ecotype, together with numerous minor transcripts that vary by one or two bases.

\section{PCR-Based Isolation of Transcribed 5S rDNA Units}

To isolate 5S rDNA units corresponding to the 5S RNA transcripts, we performed PCR on YACs from the CIC library. CIC YACs were mapped specifically for each $5 S$ locus. YACs 9A5, 7E7, 7G3, and 9D3 were used for chromosome 3 loci 1, 2, and 3 and chromosome 4 , respectively (this paper and Schmidt et al. 1995). The major 5S locus of the left arm of chromosome 5 is contained in YACs 6A1-4E4 (Tutois et al. 1999; Kotani et al. 1999). For the minor block on the right arm of chromosome 5, YAC 11A3 was used. YACs were used as template DNA for PCR using degenerate oligonucleotides to prevent biased amplification.

The major block of chromosome 5 was contained in both YACs 6A1 and 4E4 (Tutois et al. 1999). However, restriction polymorphism analysis of these YACs showed that some $5 \mathrm{~S}$ units are restricted to one of the two YACs. Digestion of YAC 6A1 with EcoRI and hybridization with a $5 \mathrm{~S}$ rDNA probe showed a 4-kb band, absent with YAC 4E4 (Fig. 4, lanes 1 and 2). With BamH1, a 5-kb band was found for YAC $4 \mathrm{E} 4$ only (Fig. 4, lanes 3 and 4), as well as for 4E4 5S units containing two BamH1 sites (Fig. 4, lane 3). Thus, for the major block of chromosome 5, PCR experiments and sequences were performed on YACs $6 \mathrm{~A} 1$ and $4 \mathrm{E} 4$. For the other $5 \mathrm{~S}$ blocks of the genome, only one YAC was used.

\section{Different Sets of Primers Were Used}

-dG3-dG4 were used to amplify 5S rDNA units from YACs 11A3-9D3-6A1-4E4. These degenerate primers were chosen in a region of the spacer that is very similar for these three blocks: chromosome 5 minor block (YAC 11A3), chromosome 4 (YAC 9D3), and the major block of chromosome 5 (YACS 6A1-4E4). This region displays some differences for $5 \mathrm{~S}$ loci 1 , 2 , and 3 of chromosome 3 , and primers dG5-dG6 were used, according to these differences, to amplify units from YACs 7E7 (chromosome 3 locus 2) and 9A5 (chromosome 3 locus 1 ). These two sets of primers amplify nearly complete units of 495 bp (Fig. 2B).

-dG14-dG15 were chosen to amplify units, from all of the YACs, 7G3 (chromosome 3 locus 3) included. These degenerate primers were expected to amplify complete units and give longer flanking sequence 3 ' of the transcribed region than the primers cited above (Fig. 2B).

PCR products were sequenced and compared with 5S RNA transcript sequences. All of the sequences presented here 
A

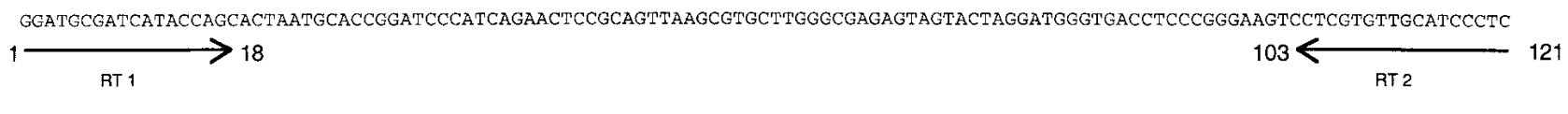

B Thunscribued Truascribled

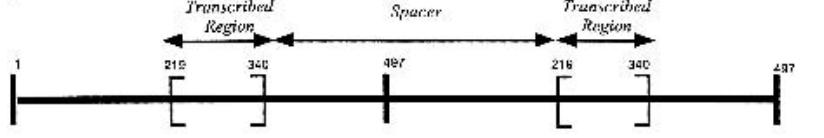

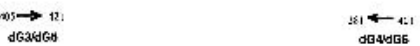

$\underset{\substack{x \rightarrow \infty \\ 4314}}{\text { de15 }}$

correspond to different units as shown by the differences in the sequences of the transcribed or spacer regions. Two groups of $5 \mathrm{~S}$ rDNA units were defined. The first group comprises $5 \mathrm{~S}$ rDNA units that do not have RNA equivalent. The second group is of more biological interest because it corresponds to $5 \mathrm{~S}$ rDNA units having 5S RNA equivalents. These results are presented below.

\section{S Units of Chromosome 3 Loci 1, 2, and 3 and Chromosome 5 Minor Block}

Sequences of $5 \mathrm{~S}$ rDNA units from chromosome 3 loci 1, 2, and 3 and chromosome 5 minor block were aligned with 5S RNA sequences. We did not find any $5 \mathrm{~S}$ rDNA sequence corresponding to $5 \mathrm{~S}$ transcript sequences.

A consensus sequence from the transcribed region was drawn from 24 sequences obtained from YAC 11A3 (chromosome 5 minor locus), 15 sequences from YAC 9A5 (5S locus 1 of chromosome 3), 60 sequences from YAC 7E7 (5S locus 2 of chromosome 3), and seven sequences from YAC $7 \mathrm{G} 3$ (chromosome 3 locus 3). Alignment of these four consensus sequences with the sequence of the major $5 \mathrm{~S}$ transcript is presented in Figure 5.

For YAC 11A3 (chromosome 5 minor block), alignment revealed differences throughout the sequence. Mutations at positions 2, 25, and 30 are fixed, whereas those at position 29, $70,71,72$, and 74 were found in $88 \%$ to $96 \%$ of sequenced $5 \mathrm{~S}$ rDNA units from this block. In addition to these mutations, $5 \mathrm{~S}$ units present an average of two mutations compared with the consensus sequence.

For YAC 9A5 (locus 1 of chromosome 3), 5S rDNA units showed one fixed mutation at position 99. Mutations at positions 30 and 96 were found in 50\% and 93\% of the sequenced units, respectively. Other mutations are found all along the sequenced 5S rDNA units.

For YAC 7E7 (locus 2 of chromosome 3), the same fixed mutation seen in locus 1 was observed at position 99 , whereas other mutations compared with the consensus sequence were observed in $60 \%$ to $70 \%$ of the $5 \mathrm{~S}$ rDNA units. As for locus 1 , other mutations were also observed, the number varying from six to 12 per DNA sequence.

For YAC 7G3 (locus 3 of chromosome 3), only the mutation at position 99 is fixed; others found at positions 1 and 96 were present in $57 \%$ of the sequenced units from this block. An average of eight mutations were also present.

All the 5S rDNA units from chromosome 3 and chromosome 5 minor block differ from the sequenced 5S RNAs by the presence of numerous mutations. We conclude that $5 \mathrm{~S}$ arrays localized on chromosome 3 and chromosome 5 minor block
Figure 2 Positions of the primers used for RT-PCR and PCR experiments. (A) Sequence of $5 S$ rDNA-transcribed region whose size is 121-bp long and primers RT1-RT2. (B) Two consecutive 5S rDNA units are represented; PCR products are expected to be $495 \mathrm{bp}$ with Oldg3-Oldg4 and Oldg5-Oldg6 and 491 bp with Oldg14-Oldg15.

are either not transcribed or give 5S RNA that are immediately degraded by quality-control mechanisms and undetectable in this analysis. In addition, we have analyzed the $5 \mathrm{~S}$ units present in the corresponding BACs (Fig. 1), enhancing considerably the number of $5 \mathrm{~S}$ units analyzed. BACs and YACs $5 \mathrm{~S}$ sequences analyses completely agree in the absence of corresponding 5S RNA.

\section{S Units of Chromosome 4 and Major Block of Chromosome 5}

Thirty-five sequences of YAC 9D3 (chromosome 4) and 164 sequences of YACs 6A1 and 4E4 (major block of chromosome 5 ) were compared with $5 S$ RNA sequences. Some 5S RNA transcripts have the same sequence as the corresponding $5 \mathrm{~S}$ rDNA units localized on these two $5 \mathrm{~S}$ loci, although the majority of the transcripts correspond to 5S rDNA units found at only one locus. The details are summarized below and in the second column of Figure 3.

Six sequences from chromosome 4 (YAC 9D3; 17\%) and 36 from chromosome 5 major block (YACs $6 \mathrm{~A} 1$ and $4 \mathrm{E} 4 ; 22 \%$ ) are identical to the major 5S RNA transcript (Fig. 3, lane 1). Minor transcript m91(T) is also identical to rDNA sequences of both loci: four rDNA units of chromosome 4 and three of chromosome 5 major block were identified (Fig. 3, lane 10).

The other 5S RNA transcripts show identical 5S rDNA units at only one 5S locus. Minor transcript m78(T) corresponds to three rDNA units of YAC 9D3 mapped on chromosome 4 (Fig. 3, lane 5). The following are each identical to one or several units of chromosome 5 major block: m53(C), m59(C), m47(T), m52(C), m93(A) and m51(A) (Fig. 3, lanes 2, 9, and 11-14).

Furthermore, sequencing of the $5 \mathrm{~S}$ rDNA units restricted to YAC $6 \mathrm{~A} 1$ or YAC $4 \mathrm{E} 4$ was performed. The YAC $6 \mathrm{~A} 1-4-\mathrm{kb}$ band obtained by EcoRI digestion (Fig. 4, lane 2) and the YAC 4E4-5-kb band obtained by BamHI digestion (Fig. 4, lane 3) were purified. PCR experiments were performed followed by sequencing. Thirty percent of these new units from $6 \mathrm{~A} 1$ and $20 \%$ from $4 \mathrm{E} 4$ are identical to the $5 \mathrm{~S}$ major transcript. The only minor transcript with corresponding rDNA sequences specific to YAC $4 \mathrm{E} 4$ is $\mathrm{m} 53(\mathrm{C})$.

These results show that the YACs 6A1 and 4E4 mapped on chromosome 5 major block contain the majority of the $5 \mathrm{~S}$ rDNA units corresponding to $5 \mathrm{~S}$ major or minor transcripts. As shown with minor transcripts, we can conclude that chromosome 5 major block, and not $5 \mathrm{~S}$ units restricted to YACs $6 \mathrm{~A} 1$ or $4 \mathrm{E} 4$, produces the majority of mature 5S RNA; however, we cannot exclude some contribution of $5 \mathrm{~S}$ units from chromosome 4. 


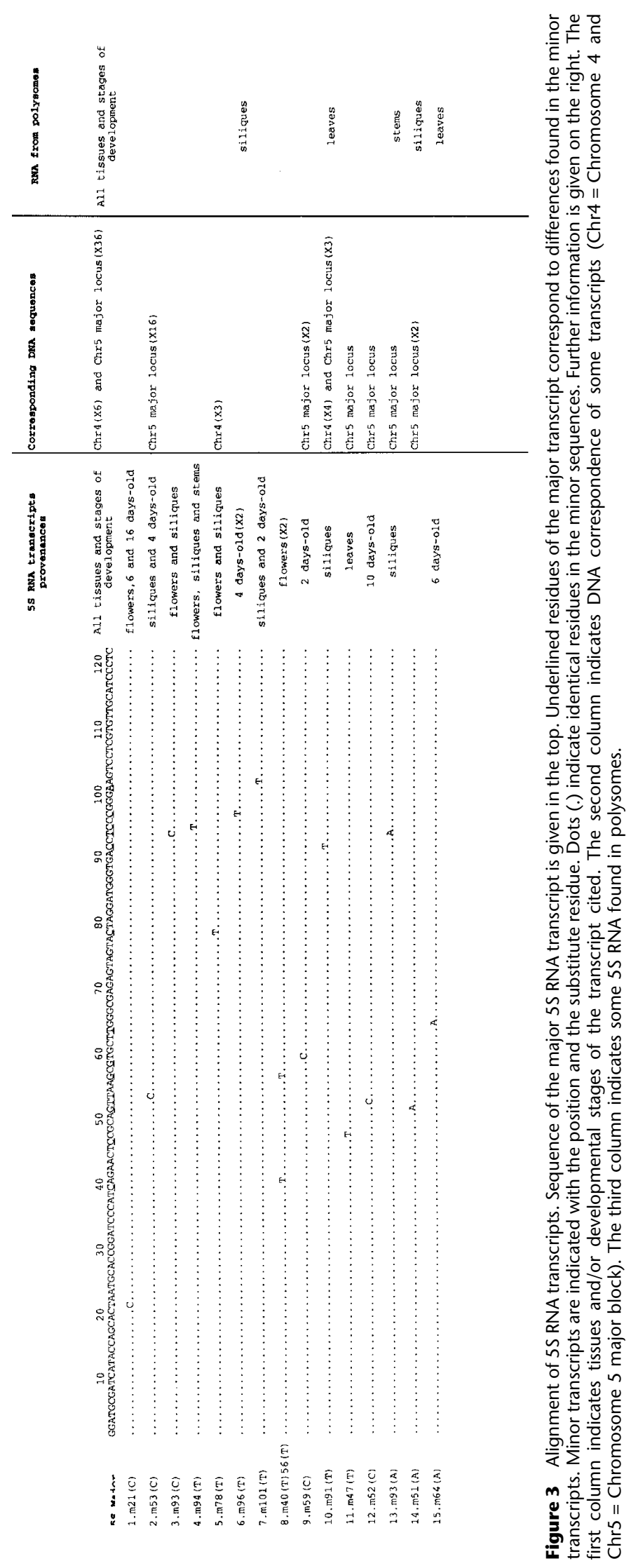

Genome Research 


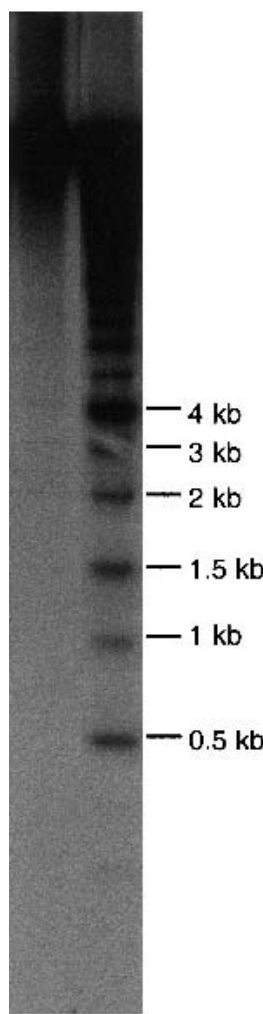

12

Figure 4 Southern blot of yeast-recombinant DNA probed with $5 S$ rDNA. Lanes 1 and 2 are EcoRI digestion of YAC 4E4 and 6A1, respectively. Lanes 3 and 4 are Bam $\mathrm{H} 1$ digestion of YACs $4 \mathrm{E} 4$ and $6 \mathrm{~A} 1$, respectively.

\section{S RNA from Polysomes}

To investigate which 5S RNA is present in ribosomes, polysomes from flowers, leaves, stems, siliques, and 16-d-old plants were purified. RNA was isolated and RT-PCR performed with oligonucleotides RT 1 and RT 2 (Fig. 2A).

Of the 135 sequenced RNAs from polysomes, 118 are identical to the major 5S RNA transcript (87\%). The 17 remaining sequenced products correspond to minor transcripts. The details are presented in Figure 3, column 3.

Four of the 17 minor transcripts had already been identified in the different tissue and developmental stage RNAs studied (Fig. 3, lanes 6, 10, 13, and 15), and two among these four also have identical DNA sequences (Fig. 3, lanes 10 and 13). The minor transcript m51(A) has only one identical corresponding DNA sequence on chromosome 5 major block (Fig. 3, lane 14). The 12 remaining minor transcripts observed in polysomes were each found only once and do not correspond to any sequenced rDNA unit.

The presence of minor transcripts in polysomes shows that the major $5 \mathrm{~S}$ transcript is not the only functional transcript in polysomes, and that the mutations they carry probably do not prevent correct folding. Furthermore, as shown above, only DNA corresponding sequences from chromosome 5 major block were found.

\section{In Vitro Transcription}

The internal control region (ICR) recognized by polymerase III was defined by comparison of the transcribed region of $5 \mathrm{~S}$ rDNA genes of $A$. thaliana with the transcribed region of other eukaryotic $5 \mathrm{~S}$ rDNA genes. It consists of an A box (50-61), an intermediate element (IE, 67-72), and a C box (80-89) (Cloix et al. 2000 and Fig. 6A). As shown in other plants, 5S rDNA units present a short TATA-like sequence at - $30 \mathrm{bp}$, a $\mathrm{G}+\mathrm{C}$ rich region at about $-13 \mathrm{bp}$ and a $\mathrm{C}$ at -1 (Venkateswarlu et al. 1991).

We have tested the transcription potential of the $5 \mathrm{~S}$ sequences from the different $5 \mathrm{~S}$ blocks of the genome using the in vitro system from tobacco developed by Fan and Sugiura (1996) and improved by Yukawa et al. (1997). The control is represented by a complete (495 bp) $5 \mathrm{~S}$ unit from the chromosome 5 major block, subcloned in the pGem T-plasmid (Fig. 7). It contains a transcribed region homologous to the major 5S RNA and a 5 '-flanking region containing the TATA motif, the $\mathrm{G}+\mathrm{C}$-rich region at $-13 \mathrm{bp}$, and the $\mathrm{C}$ at -1 (Fig. 6A).

\section{Chromosome 3 Loci 1 and 2}

First of all, $88 \%$ and $94 \%$ of the 5 S units from chromosome 3 loci 1 and 2, respectively, contain a TAGA motif (or TACA in some cases), instead of the TATA motif. The in vitro tested 5S unit is representative of these blocks because it contains the TAGA motif and ten mutations in the transcribed region (the mean value is nine mutations per sequence). As shown in Figure 7, no transcript is detected in vitro. We have confirmed that with only the $T \rightarrow G$ mutation (creating the GAGA motif), no transcript is revealed (when compared with the control construct) (Fig. 7).

Twelve percent of the $5 \mathrm{~S}$ units from locus 1 and $6 \%$ of the $5 \mathrm{~S}$ units from locus 2 have the TATA motif, but $74 \%$ have a mutated base at the first base of the transcribed region, which is known to abolish in vitro transcription of a tRNA gene in the same in vitro transcription system (Yukawa et al. 2000 and pers. comm.). In addition, all these $5 \mathrm{~S}$ units have a mean value of nine mutations in the transcribed region, arguing, as for the in vivo situation, that if these $5 \mathrm{~S}$ units are transcribed, the $5 \mathrm{~S}$ transcripts are immediately degraded by qualitycontrol mechanisms.

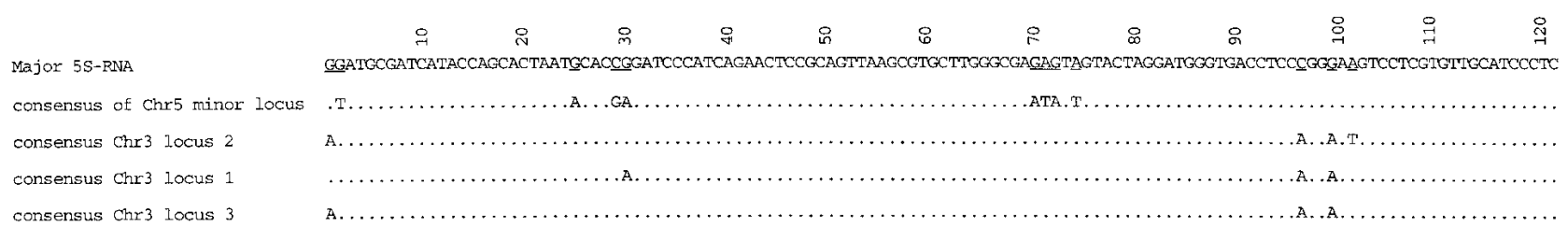

Figure 5 Alignment of the transcribed region consensus sequences of 24 sequences from chromosome 5 minor block, 60 sequences from locus 2, 15 sequences from locus 1, and seven sequences from locus 3 of chromosome 3 with the major 5 S RNA transcript. Dots (.) indicate identical residues. Different residues are underlined in the major 5S RNA sequence. 

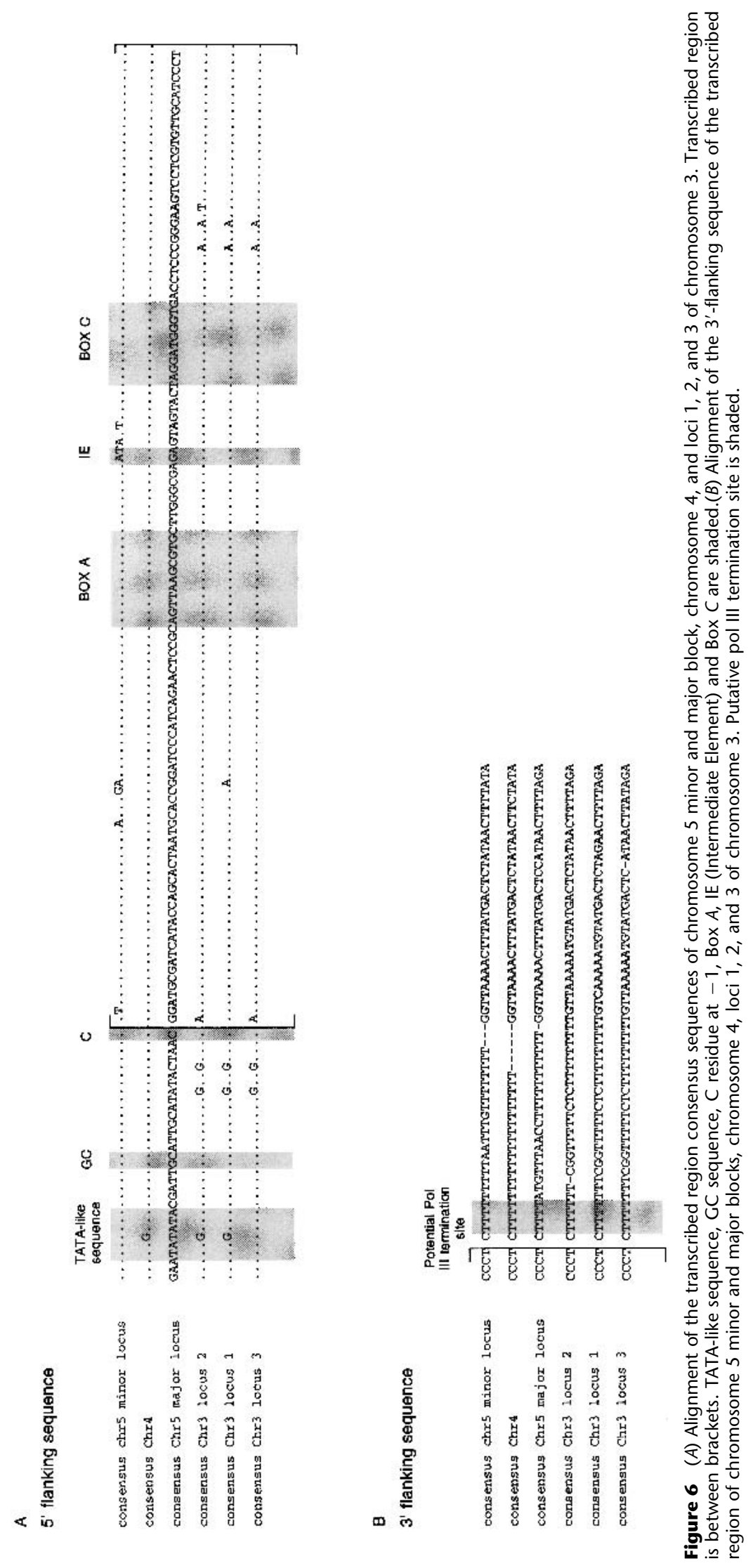

Genome Research 


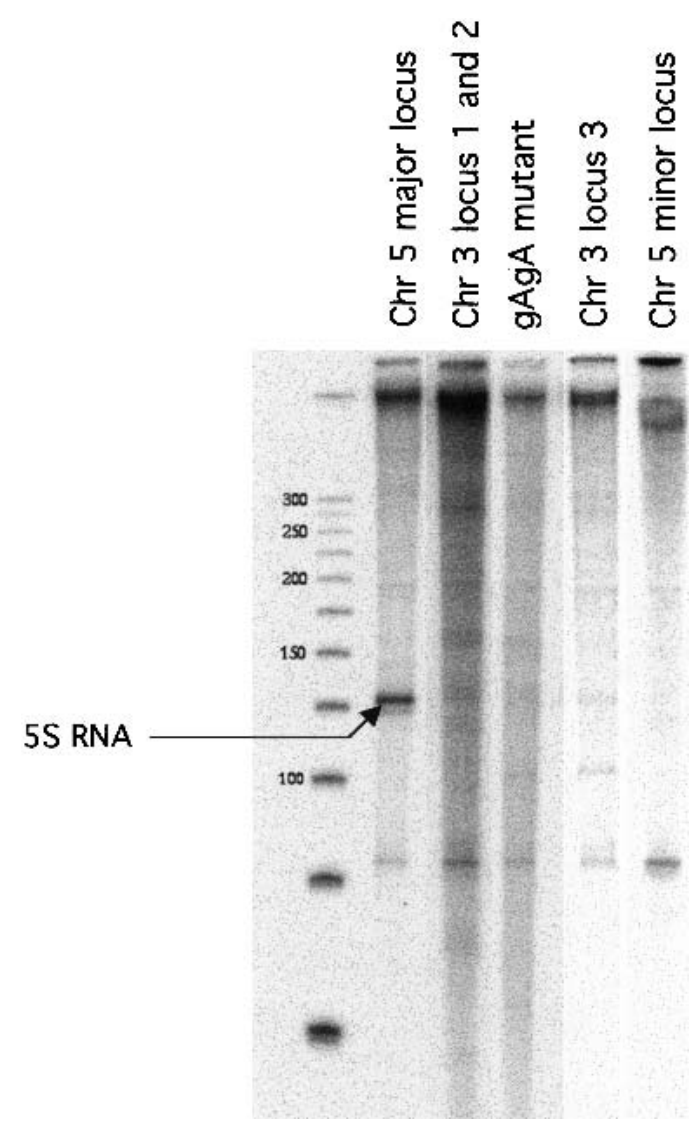

Figure 7 In vitro transcription.

\section{Chromosome 3 Locus 3}

Two 5S units from chromosome 3 locus 3 showed no transcript in the in vitro test (Fig. 7, only one construct is shown). Only $57 \%$ of the $5 \mathrm{~S}$ units from this block have the TATA motif. The two tested 5S units do have a TATA motif, but, as $71 \%$ of the sequenced $5 \mathrm{~S}$ units, they have a mutation at the first base of the transcribed region (Fig. 6A). In addition to the fixed mutation at position 99, they carry nine and six mutations, respectively, the mean value being nine in the transcribed region.

\section{Chromosome 5 Minor Block}

$5 \mathrm{~S}$ units from the chromosome 5 minor block do have a $5^{\prime}$ flanking region with the TATA, GC, and C motifs but contain numerous mutations in the transcribed region (Fig. 6A). The $5 \mathrm{~S}$ unit tested in vitro is representative of $5 \mathrm{~S}$ units from this block because it contains the fixed mutations $2 \mathrm{~T}, 25 \mathrm{~A}, 30 \mathrm{~A}$ and the mutations present in $96 \%$ (29G, 70A, $71 \mathrm{~T}$, and $72 \mathrm{~A})$ or $91 \%(74 \mathrm{~T})$ of the $5 \mathrm{~S}$ units. With this $5 \mathrm{~S}$ unit, no transcript was detected in vitro (Fig. 7). By sequence comparison with the well-characterized Xenopus model (Pieler et al. 1987), the intermediate element (one of the three boxes from the internal promoter) is between positions 67 and 72 . Nearly all the $5 \mathrm{~S}$ units from the chromosome 5 minor block (96\%) have mutations at position $70 \mathrm{~A}, 71 \mathrm{~T}$, and $72 \mathrm{~T}$, which could participate to the transcription inhibition or to the recognition by the degradation mechanism.

These in vitro results correlate with those obtained in vivo, in which only $5 \mathrm{~S}$ blocks (such as that from chromosome
4 and chromosome 5 major block ) with 5 S units homologous to the major RNA or containing very few mutations produce mature 5S RNA.

\section{0-Bases 5S RNA Molecule}

The consensus 5S RNA-transcribed region of 121 bases was defined by sequence homologies (Campell et al. 1992). However, in all the plants studied, the 5S RNA is a 120 bases molecule (Ellis et al. 1988), including A. thaliana (Barciszewska et al. 1994). To resolve the size of the mature 5S RNAs, we performed 3'-anchored PCR followed by sequencing (see Methods section). This experiment led to the conclusion that the transcript ends with the $\mathrm{T}$ residue and therefore is 120 bases long (Fig. 6A).

\section{Flanking Regions Specific to 5S rDNA Arrays}

Polymerase III can recognize a simple cluster of four or more $T$ residues as terminator signals (reviewed by Paule and White, 2000). In A. thaliana, this T stretch differs between units according to their location: chromosome 3 loci 1, 2, and 3, chromosome 4, and chromosome 5 major and minor blocks (Fig. 6B). All units from chromosome 4 (YAC 9D3) present a long uninterrupted stretch of $\mathrm{T}$ residues (19 up to $21 \mathrm{~T}$ ). For the units of the other YACs, this stretch of T residues is always interrupted by motifs which are specific for each locus. Thus, except for loci 1, 2, and 3 of chromosome 3 (YACs 9A5, 7E7 and 7G3), which present a weak, different cluster of $\mathrm{T}$ residues, each 5S rDNA locus can be recognized with this specific signature (and there is a chromosome-specific signature).

\section{Organization of the 5S Units in Chromosome 5 Major Block}

As shown above, we have accumulated $5 \mathrm{~S}$ rDNA sequences from chromosome 5 major block (YACs 6A1 and 4E4) and from units restricted to each YAC (bands 6A1-EcoRI and 4E4BamHI, Fig. 4) defining three 5S domains. Analysis of the transcribed region sequences revealed specific mutations for each of these three $5 \mathrm{~S}$ domains, as well as mutations shared by these three domains (Fig. 8). For example, mutation m98(T) is present in $25 \%$ of the $5 \mathrm{~S}$ units, alone or associated with other mutations, although this mutation is less represented in 4E4restricted units. These three domains contain specific mutations observed several times: $\mathrm{m} 17(\mathrm{~A}), \mathrm{m} 96(\mathrm{~T}), \mathrm{m} 97(\mathrm{~A})$ in 6A1EcoRI, m91(T), m55(T), m59(C) in chromosome 5 major block, and $\mathrm{m}$ 13(G), m53(C) in 4E4-BamHI. These results have permitted us to map $5 \mathrm{~S}$ units along the chromosome 5 major block into the three domains (Fig. 8).

\section{DISCUSSION}

We have used a combination of DNA and RNA sequences analyses to examine the organization and expression of $5 \mathrm{~S}$ rRNA genes in Arabidopsis thaliana. 3'-anchored PCR defined the 120-bp length of the $5 \mathrm{~S}$ transcribed region, in agreement with the results of Barciszewska et al. (1994), but previously defined as $121 \mathrm{bp}$ long by Campell et al. (1992). Sequence heterogeneity was observed in the $5 \mathrm{~S}$ rRNA of all $A$. thaliana tissues, developmental stages examined, and polysomal RNA. In addition to the major 5S RNA species, minor RNA species represent $18 \%$ of total 5S RNA. Heterogeneity in 5S RNA has also been reported for a wide range of organisms including bacteria (Jarry and Rosset, 1971), fungi (Wildelman and Nazar, 1982; Chen et al. 1984), echinoderms (Lu et al. 1980), arthropods (Komiya et al. 1980), amphibia (Ford and South- 

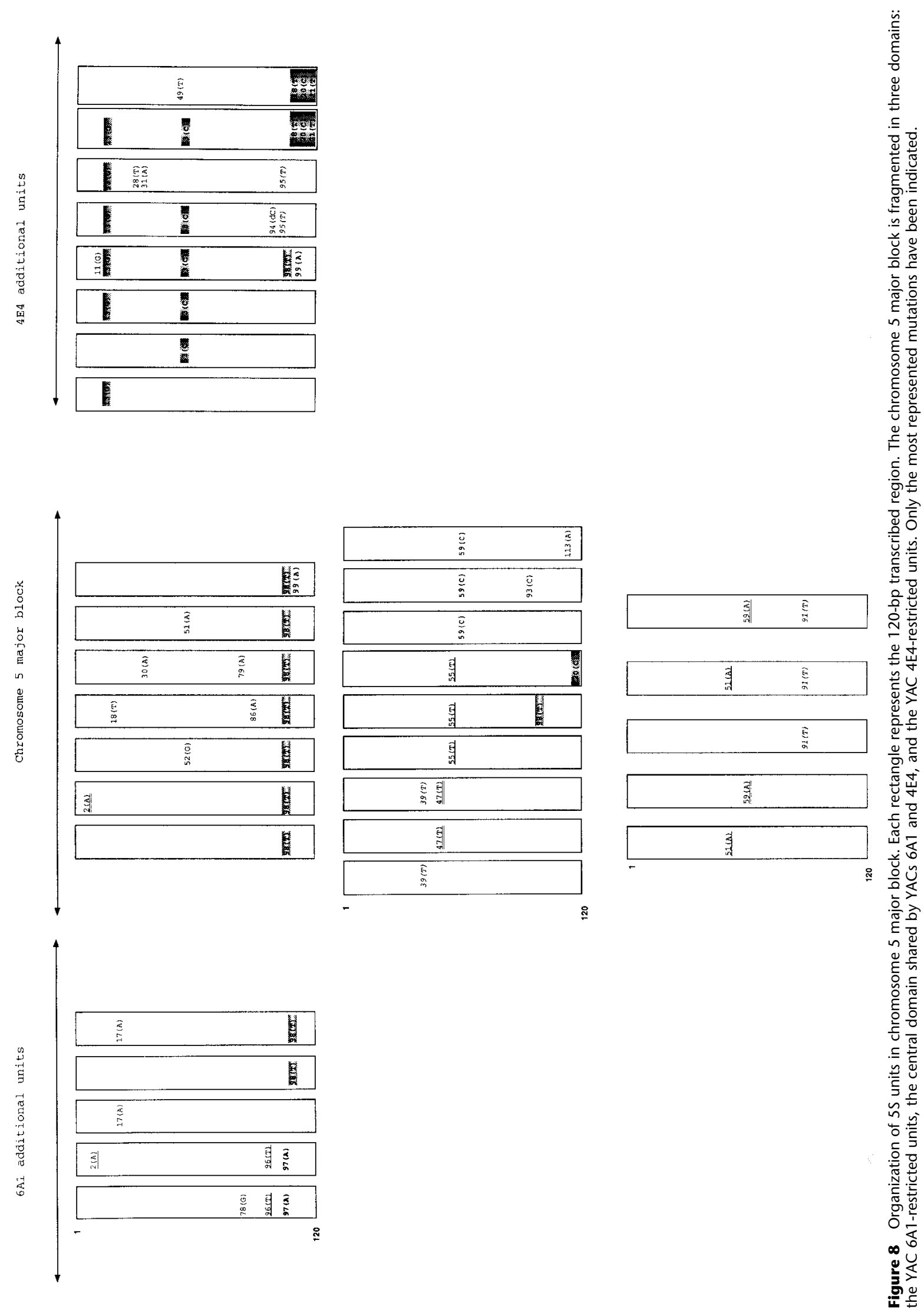
ern, 1973; Ford and Brown, 1976), birds, and mammals (Ro-Choi et al. 1971; Knight and Darnell, 1967; Krol et al., 1981).

A. thaliana minor 5S RNAs differ from the major 5S RNA by one or two base substitutions, as has been described for Escherichia coli (Jarry and Rosset, 1971), and we found many different 5S RNA, as reported in Neurospora (Chen et al. 1984). However, only in Escherichia coli, Xenopus, and Neurospora (Selker et al. 1985), has it been shown that heterogeneous 5S RNA exist in polysomes. At this time we do not know if some types of 5S RNA are rejected during ribosome assembly. Thus, there is either a functional heterogeneity of the ribosomal $60 \mathrm{~S}$ subunits or, and we believe more likely, the nucleotide substitutions identified in the minor RNA do not hamper the functions of 5S RNA. Two different explanations can be advanced for the presence of minor 5S rRNA: (1) Minor 5S rDNA sequences are transcribed because of a need for a high level of 5S RNA synthesis, and major DNA sequences cannot produce enough 5S RNA. We have shown that in the highly active transcriptional states ( 2 and $4 \mathrm{~d}$ after germination), the proportion of minor 5S RNA goes up to $25 \%$. (2) The repression of minor $5 \mathrm{~S}$ rDNA sequences is not completely efficient. Minor sequences adjacent to major sequences escape the repression. In our data, all transcribed sequences leading to major and minor 5S RNA are located in the same 5S block. We cannot now discriminate between these two hypotheses.

Using a comparison of DNA and RNA sequences, we show that the $5 \mathrm{~S}$ blocks from chromosome 3, as well as from the chromosome 5 minor block, do not participate to the $5 \mathrm{~S}$ RNA pool. So, either they are not transcribed or they produce $5 S$ RNAs that are rapidly degraded. In vitro results agree with in vivo results, because we did not detect transcripts for $5 \mathrm{~S}$ units from chromosome 3 loci 1, 2, 3, and chromosome 5 minor locus. The presence of different types of mutations, such as the absence of the TATA box or mutations in the internal promoter, is the presumed cause of this absence of mature transcripts. In vitro experiments in Drosophila melanogaster (Sharp and Garcia, 1988), Bombyx mori (Morton and Sprague, 1984), Neurospora crassa (Tyler, 1987), and nematodes (Nelson et al. 1998) showed that 5S transcription requires the presence of upstream sequences, especially the TATA box. The TATA-like motif is absent from almost all 5S units of chromosome 3 loci 1 and 2. In contrast, some 5 S units from chromosome 3 locus 3 and the chromosome 5 minor block do contain this motif but $5 \mathrm{~S}$ transcripts are not detectable, other mutations apparently responsible for this nontranscription or 5S RNA rapid degradation. Therefore, either these blocks do not have the potential to be transcribed or the transcripts are already degraded after 90 min of incubation. However, some other $5 \mathrm{~S}$ mutant types are still present at this time (not shown). We find the TATA-like motif to be present in $100 \%$ of the $5 \mathrm{~S}$ units from the chromosome 5 major block, origin of the majority of mature 5S RNA. It is only present in $40 \%$ of the $5 \mathrm{~S}$ units from chromosome 4 , in agreement with the results indicating that the contribution of chromosome 4 is minor.

In Xenopus laevis, there is a developmental control of the $5 \mathrm{~S}$ gene expression. The somatic gene family (400 copies organized in tandem) is expressed in both oocytes and somatic cells, whereas the oocyte-type genes (20,000 copies tandemly arranged on several chromosomes) are only expressed during oogenesis and early embryogenesis, and the appearance of histone $\mathrm{H} 1$ in embryonic chromatin correlates with the establishment of repression of oocyte 5 S genes (Wolffe, 1989). The
60-Kd Ro protein forms complexes with defective precursors of 5S RNA in Xenopus oocytes. The mutant RNAs are processed inefficiently to mature 5S RNA. They are less stable than the wild-type 5S RNA precursors and eventually degrade $\left(\mathrm{O}^{\prime}\right.$ Brien and Wolin, 1994). The Ro protein binds 5S RNA precursors containing a variety of internal mutations while discriminating against the wild-type 5S RNA. This protein may function as part of a novel discard, or quality control, pathway for abnormal 5S RNA precursors (Shi et al. 1996). Discard pathways for variant 5S RNA molecules may also exist in Arabidopsis and other species.

The silencing of $5 \mathrm{~S}$ blocks has not been described, but this type of investigation necessitates knowledge of the origin of each 5S unit. The availability of mapped YACs allowed us to sequence $5 \mathrm{~S}$ units from identified $5 \mathrm{~S}$ blocks. Gerlach and Dyer (1980) suggested that only the short 5S repeat unit was transcriptionally active in wheat, with the different repeats (short and long) organized in separate clusters, each cluster on a separate chromosome (Dvorak et al. 1989). In the case of the absence of transcription of some Arabidopsis 5S blocks, what mechanisms could have led to this extinction? Several studies have indicated that Arabidopsis could be a degenerate tetraploid because a minimum of $60 \%$ of its genome is found as duplications (Kowalski et al. 1994; AGI, 2000a; Grant et al. 2000; Blanc et al. 2000). Results are in favor of a model of tetraploidy followed by translocation (Wolfe and Shields, 1997). Therefore, the modern Arabidopsis contains thousands of 5S rDNA genes, and it was suggested that only a fraction of $5 \mathrm{~S}$ genes, as well as $45 \mathrm{~S}$ genes, are active because the number of rRNA genes far exceeds that normally required to supply ample cytoplasmic rRNA (reviewed by Rogers and Bendich, 1987). Nucleolar dominance is a phenomenon in plant (Brassica, Arabidopsis, Pikaard, 1999) and animal (Xenopus, Honjo and Reeder, 1973) hybrids in which one parental set of ribosomal 45S RNA genes is transcribed, but the hundreds of rRNA genes inherited from the other parent are transcriptionally silent. Possibly, the same repression mechanisms that control the nucleolar dominance in hybrids may be responsible for the control of the number of active genes within a pure species (Wallace and Langridge, 1971), and they probably reflect a dosage-compensation mechanism (Pikaard, 1999). The absence of 5S RNA polymorphism, up to now, prevented the search for a " $5 \mathrm{~S}$ dominance," but the high number of $5 \mathrm{~S}$ and $45 \mathrm{~S}$ rDNA units indicates a dosage compensation mechanism for $5 \mathrm{~S}$ genes and could explain the noncontribution of some 5S loci to the 5S RNA pool. Fransz et al. (1998) have observed that some ecotypes (WS, C24, and LER) are devoid of $5 \mathrm{~S}$ loci on chromosome 3, without known deleterious effects.

In addition, the fact that $5 \mathrm{~S}$ blocks are in the pericentromeric heterochromatin and contain highly homogeneous $5 \mathrm{~S}$ units tandemly arranged (only 6\% divergence in 5S arrays that do not contribute to the 5S RNA pool; Cloix et al. 2000) reminds the satellite sequences, heterochromatic and which can also be highly homogeneous. Some satellites can also be highly homogeneous, despite the absence of obvious functional significance, and are present in homologous genome locations in closely related species (fish: Franck and Wright, 1993; Drosophila: Bachmann and Sperlich, 1993; Heikkinen et al. 1995; Triticeae: Vershinin et al. 1996; and Insecta: Mestrovic et al. 2000). Other satellites may be under functional constraints to conserve short sequence motifs such as those found in avian satellite (Madsen et al. 1994), in primate $\alpha$ satellite (Romanova et al. 1996), or in the Arabidopsis 180-bp satellite 
(Heslop-Harrison et al. 1999). Satellite sequences have often been considered "junk" DNA, but DNA "bulk" surrounding the centromere seems to be necessary for eukaryotic chromosome function.

The accumulated sequence data have permitted us to establish sequence signatures specific for each $5 \mathrm{~S}$ block, particularly a $\mathrm{T}$ stretch, $3^{\prime}$ from the transcribed region specific for each $5 \mathrm{~S}$ array. An exception remains for loci 1, 2, and 3 of chromosome 3. $5 \mathrm{~S}$ sequences from these blocks situated on the same chromosome region display very few differences. In cotton, polymorphisms are shared between two close $5 \mathrm{~S}$ arrays, both in the $5 S$ gene and spacer (Cronn et al. 1996). We are not aware of any case in which interlocus-concerted evolution of $5 \mathrm{~S}$ rDNA arrays has been shown in plants. The available information indicates that the predominant homogenizing forces acting on $5 \mathrm{~S}$ ribosomal genes and spacers operate at the level of the individual arrays (Cronn et al. 1996).

Accumulation of $5 \mathrm{~S}$ rDNA sequences from chromosome 5 major block (YACs 6A1 and 4E4) and from units restricted to these two YACs (bands 6A1-EcoRI and 4E4-BamHI, Fig. 4) allowed us to define three $5 \mathrm{~S}$ domains. The sequence of the transcribed region of these three $5 \mathrm{~S}$ domains revealed specific mutations and mutations shared by these three domains. Using these mutations, we have mapped 5S rDNA units all along the chromosome 5 major block. Different conclusions can be drawn: (1) It is clear that $5 S$ arrays result from the phenomenon fixation-amplification of some 5S rDNA units. (2) Recombination events such as unequal crossingover between two 5S rDNA units harboring only one mutation lead to $5 \mathrm{~S}$ rDNA units with both mutations $(\mathrm{m} 13(\mathrm{G})+\mathrm{m} 53(\mathrm{C})=\mathrm{m} 13(\mathrm{G}) 53(\mathrm{C}))$, which can further be amplified. (3) 4E4-restricted units localized at the centromereproximal side of chromosome 5 major block contain the highest number of mutations. (4) Although we did not find the 5S rDNA sequence producing some minor 5S RNA transcripts as $\mathrm{m} 96(\mathrm{~T})$, they probably come from this chromosome 5 major block because they carry mutations specific to this block, strengthening the conclusion that the greater part of $5 \mathrm{~S}$ RNA are produced by the chromosome 5 major block.

\section{METHODS}

\section{RNA Isolation}

Homogenization of tissue samples was performed in $1 \mathrm{~mL}$ of trizol reagent (GibcoBRL) per $50-100 \mathrm{mg}$ of tissue using a power homogenizer (polytron). Homogenized samples were incubated for $5 \mathrm{~min}$ at room temperature and insoluble material was removed from the homogenate by centrifugation at $12,000 \mathrm{~g}$ for $10 \mathrm{~min}$ at $4^{\circ} \mathrm{C} ; 0.2 \mathrm{~mL}$ of chloroform per $\mathrm{mL}$ of trizol reagent was added to the supernatant containing the RNA. Tubes were shaken vigorously by hand for $15 \mathrm{sec}$, incubated at room temperature for $2 \mathrm{~min}$, and centrifuged at $12,000 \mathrm{~g}$ for $15 \mathrm{~min}$ at $4^{\circ} \mathrm{C}$. The aqueous phase, containing RNA, was transferred to a fresh tube. Precipitation of RNA was performed by the addition of $0.5 \mathrm{~mL}$ of isopropyl alcohol per milliliter of trizol reagent. Mixing and incubation of samples were performed at room temperature and centrifugation at $12,000 \mathrm{~g}$ for $10 \mathrm{~min}$ at $4^{\circ} \mathrm{C}$ was performed. Then, $0.5 \mathrm{~mL}$ of $\mathrm{H}_{2} \mathrm{O}$ diethylpyrocarbonate (DEPC) was added to the pellet, and RNA was reprecipitated with $1 / 10$ volume of sodium acetate $3 \mathrm{M}$ and 2 volumes of ethanol $100 \%$. Samples were centrifuged for $10 \mathrm{~min}$ at $12,000 \mathrm{~g}$ at $4^{\circ} \mathrm{C}$. The RNA pellet was dried (air- or vacuum-dry) for $5 \mathrm{~min}$ and resuspended in 0.1 $\mathrm{mL}$ of $\mathrm{H}_{2} \mathrm{O}$ DEPC.

\section{Reverse Transcription}

One $\mu g$ of total RNA was incubated with 10 units of DNaseI (Promega) and 40 units of RNAsin (Promega) for $10 \mathrm{~min}$ at $37^{\circ} \mathrm{C}$. DNaseI was inactivated by incubation for $10 \mathrm{~min}$ at $65^{\circ} \mathrm{C}$, then removed by an extraction phenol/CIA (chloroform/isoamyl alcohol 1:25), followed by an extraction with CIA only. The final aqueous phase was incubated with $1 / 10$ volume of sodium acetate $3 \mathrm{M}$ and 2 volumes of ethanol $100 \%$ for $2 \mathrm{~h}$ at $-20^{\circ} \mathrm{C}$. RNA was pelleted by centrifugation at $14,000 \mathrm{rpm}$ for $15 \mathrm{~min}$ at room temperature. The RNA pellet was washed, dried, and dissolved in $20 \mu \mathrm{L} \mathrm{H}_{2} \mathrm{O}$ (DEPCtreated). Ten $\mu \mathrm{L}$ of the RNA sample (500 ng) were incubated for $1 \mathrm{~h}$ at $37^{\circ} \mathrm{C}$ with 10 units AMV reverse transcriptase (Promega), 1X RTase buffer, $6 \mu \mathrm{g}$ random hexameric oligonucleotides, $0.01 \mathrm{M}$ DTT, $0.2 \mathrm{mM}$ dNTP, and 30 units of RNAsin in a $30 \mu \mathrm{L}$ reaction volume.

\section{PCR Amplification}

5S rDNA units were amplified by PCR using CIC YACs as template DNA (Creusot et al. 1995). The primer sequences, the positions of which are given in Figure 2B, were: dG3: GNCAAANTTNGCATGTG and dG4: CNGTNTANAAGT TATNGAGTC. dG5: GTATNNCATGCNANGTNTNG and dG6: CNGAAANCCNAAAGAGANC dG14:CGTGATTTGGGCT ATATTACG and dG15: CCCGAAAAAGTANNTAAAGGTC.

The amplification reactions were performed in a $50-\mu \mathrm{L}$ volume with 5 units of Goldstar Taq Polymerase (Eurogentec) following the manufacturer protocol $\left(2.5 \mathrm{mM} \mathrm{MgCl}_{2}, 1 \mathrm{X}\right.$ goldstar buffer, $1 \mu \mathrm{M}$ of each primer, and $0.25 \mathrm{mM}$ dNTP). After denaturation for $5 \mathrm{~min}$ at $95^{\circ} \mathrm{C}, 30$ amplification cycles were performed, each consisting of denaturation at $95^{\circ} \mathrm{C}$ for 30 seconds, annealing at Tm for 30 seconds and primer extension at $72^{\circ} \mathrm{C}$ for 30 seconds.

For transcription analysis, PCR was performed in the same conditions with $40 \mathrm{ng}$ of reverse-transcribed sample, 40 ng of RNA treated with DNaseI not reverse transcribed, and $40 \mathrm{ng}$ of genomic DNA. The primer sequences used after reverse transcription (positions are indicated in Fig. 2A) were: RT 1: GGATGCGATCATACCAGC and RT 2: GAGGGATGCAACACGAGG

PCR products were purified with a PCR purification kit (Qiagen).

\section{Subcloning and Sequencing}

PCR products were subcloned in the pGem-T easy plasmid using the pGem-T vector system (Promega). Sequencing was performed using the dideoxynucleotide chain termination method (Sanger et al. 1977), with the T7 DNA polymerase (Pharmacia) or the CEQ 2000 Dye terminator cycle sequencer (Beckman). Computer sequence analysis was performed with the clustawl program (www.infobiogen.fr).

\section{Preparation of Yeast-Transformant DNA}

Selective medium $(20 \mathrm{~mL})$ was inoculated with a single yeast colony and cultured at $30^{\circ} \mathrm{C}$ for $36 \mathrm{~h}$. Yeast cells were harvested by centrifugation (10 $\mathrm{min}, 2000 \mathrm{rpm}$ ), resuspended in $1 \mathrm{~mL}$ TES (100 mM Tris $\mathrm{HCl} \mathrm{pH} 8.0,100 \mathrm{mM}$ EDTA, $0.9 \mathrm{M}$ Sorbitol, $0.2 \% \beta$-mercaptoethanol, and $2 \mathrm{mg} / \mathrm{mL}$ lyticase), and incubated for $1 \mathrm{~h}$ at $37^{\circ} \mathrm{C}$. Spheroplasts were pelleted by centrifugation ( $5 \mathrm{~min}, 1200 \mathrm{rpm}$ ) and resuspended in $2 \mathrm{~mL} 50$ $\mathrm{mM}$ Tris and $20 \mathrm{mM}$ EDTA, then lysed by the addition of 100 $\mu \mathrm{L} 20 \%$ SDS and incubated for $30 \mathrm{~min}$ at $60^{\circ} \mathrm{C} .5 \mathrm{M}$ potassium acetate $(600 \mu \mathrm{L})$ was added. After centrifugation $(1200 \mathrm{rpm}$, $15 \mathrm{~min}$ ), the supernatant was recovered and $5 \mathrm{~mL} \mathrm{100 \%} \mathrm{etha-}$ nol added. After centrifugation, the pellet was resuspended in $500 \mu \mathrm{l}$ TE containing Ribonuclease A $(0.01 \mathrm{mg} / \mathrm{mL})$. The preparation was incubated for $30 \mathrm{~min}$ at $37^{\circ} \mathrm{C}$; the DNA was precipitated and resuspended in $100 \mu \mathrm{L}$ TE. 


\section{Southern Blots and Probe Labeling}

Arabidopsis thaliana genomic DNA (ecotype Columbia) was isolated from 3- to 4-wk-old plants with the CTAB method (Doyle and Doyle, 1987). The digestions were realized with 4 $\mu \mathrm{g}$ of Arabidopsis thaliana genomic DNA and 15-20 units of restriction enzyme in the recommended buffer (New England Biolabs) supplemented with $1 \mathrm{mM}$ spermidine. Digested DNA were electrophoresed in $0.8 \%$ agarose gels overnight, depurinated in $0.25 \mathrm{M} \mathrm{HCl}$, and transferred to hybond membranes (Amersham). Fifteen $\mu \mathrm{L}$ of yeast-transformant DNA were used per digestion in the same conditions as genomic DNA. DNA probes were prepared from plasmid fragments excised from gels. They were labeled with $\alpha 32 \mathrm{P}$ using a random hexamer priming method (Amersham).

\section{Polysome Isolation}

Total polysomes were isolated according to Vian et al. (1993). Then, 0.8-1.2 g of plant material was ground to a fine powder with liquid nitrogen, mixed on ice with 10-12 volumes of buffer U (200 mM sucrose RNase free) (Sigma Chemical), 200 $\mathrm{mM}$ Tris- $\mathrm{HCl}(\mathrm{pH} 8.5), 60 \mathrm{mM} \mathrm{KCl}, 30 \mathrm{mM} \mathrm{MgCl} 2,2 \mathrm{mM}$ EDTA, $2 \%$ polyethylene 10 -tridecyl ether, $1 \%$ sodium deoxycholate (DOC), and $100 \mu \mathrm{g} \mathrm{mL}^{-1}$ heparin) supplemented with $5 \mathrm{mM}$ DTT. The homogenate was strained through nylon cloth and centrifuged at $4^{\circ} \mathrm{C}$ for $5 \mathrm{~min}$ at $1000 \mathrm{~g}$ and $20 \mathrm{~min}$ at $13,000 \mathrm{~g}$. The supernatant was centrifuged over $2.5 \mathrm{~mL}$ of $50 \%$ sucrose made in buffer B (40 mM Tris- $\mathrm{HCl}$ [pH 8.5], $20 \mathrm{mM}$ $\mathrm{KCl}$, and $10 \mathrm{mM} \mathrm{MgCl}_{2}$ ) supplemented with $5 \mathrm{mM}$ DTT for 4 $\mathrm{h}$ at $200,000 \mathrm{~g}$ at $4^{\circ} \mathrm{C}$ (SW 41 rotor) in a Kontron Centrikon model 1065 ultracentrifuge. The polysomes-containing pellet was resuspended with $200 \mu \mathrm{L}$ of buffer B supplemented with $0.5 \%$ DOC and $100 \mu \mathrm{g} / \mathrm{mL}$ proteinase K. After gentle homogenization, the extract was centrifuged at $13,000 \mathrm{~g}$ for $2 \mathrm{~min}$ at $4^{\circ} \mathrm{C}$. Isolation of RNA was performed on the supernatant.

\section{3 ' Anchored-PCR}

Ten $\mu$ g of DNA-free RNA were incubated for $2 \mathrm{~h}$ at $37^{\circ} \mathrm{C}$ with $50 \mu \mathrm{mol}$ of anchor 5'Phosphate and $3^{\prime}$ blocked with ddC, 20 units of T4 RNA ligase (Biolabs), 1X T4 RNA ligase buffer, 1X BSA RNase-free, 25\% PEG, and 40 units of RNAsin (Promega). Phenol/CIA extraction was performed in $100 \mu \mathrm{L}$; the aqueous phase was frozen with $1 / 10$ volume of NaAc $3 \mathrm{M}$ and 2 volumes of ethanol $100 \%$ overnight at $-80^{\circ} \mathrm{C}$. RNA was pelleted by centrifugation at $14,000 \mathrm{rpm}$ for $15 \mathrm{~min}$ at room temperature. The RNA pellet was washed, dried, and dissolved in 20 $\mu \mathrm{L} \mathrm{H}_{2} \mathrm{O}$ DEPC. Then, RT-PCR experiments were performed with RT 1 and anchored inversed.

Anchor 5'Phosphate and 3' blocked with ddC: GACCAC GCGTATCGATGTCGA and Anchor inversed: GTCGACATC GATACGCGTGGTC.

\section{Preparation of Tobacco Nuclear Extract}

Tobacco nuclear extracts were prepared by a modification of the procedure of Fan and Sugiura (1995) and Yukawa et al. (1997). Tobacco-cultured cells (BY-2 cell line; Nagata et al. 1992) were harvested at middle log phase (ca. $85 \mathrm{~h}$ after inoculation) with Miracloth (Calbiochem) from a 1.5-L culture. The cells are digested in $500 \mathrm{~mL}$ of enzyme solution $(2 \% \mathrm{Cel}-$ lulase "Onozuka" RS [Yakult Pharmachemical] and 0.2\% Pectolyase Y-23 [Kikkoman] in the LS medium containing $0.38 \mathrm{M}$ mannitol and $3 \%$ sucrose, $\mathrm{pH} 5.5$ ) at $30^{\circ} \mathrm{C}$ for $50 \mathrm{~min}$. Protoplasts were collected by centrifugation at $250 \mathrm{~g}$ for $2 \mathrm{~min}$ at $2^{\circ} \mathrm{C}$, and washed twice with ice cold $0.38 \mathrm{M}$ mannitol $(\mathrm{pH}$ 5.5). The pellet was suspended in $300 \mathrm{~mL}$ nuclear isolation (NIB) [15 mM HEPES-KOH (pH 7.9), 18\% (w/v) Ficoll 400, 4 $\mathrm{mM} \mathrm{MgSO}_{4}, 1 \mathrm{mM} \mathrm{NaF}, 1 \mathrm{mM}$ EGTA, $0.5 \mathrm{mM}$ EDTA, $3 \mathrm{mM}$ DTT, $0.5 \mathrm{mM}$ PMSF, $0.5 \mathrm{mM}$ benzamidine hydrochloride, 1.5 $\mu \mathrm{g} . \mathrm{mL}^{-1}$ pepstatin $\mathrm{A}$, and $1 \mu \mathrm{g} . \mathrm{mL}^{-1}$ leupeptin] and for braking cell membrane, vacuum-filtrated twice through one layer of 20- $\mu \mathrm{m}$ nylon mesh (Schweiz). The filtrate was centrifuged at $2500 \mathrm{~g}$ for $12 \mathrm{~min}$ at $2^{\circ} \mathrm{C}$; the nuclear pellet was suspended with $250 \mathrm{~mL} \mathrm{NIB}$ and centrifuged at $2500 \mathrm{~g}$ for $10 \mathrm{~min}$ at $2^{\circ} \mathrm{C}$. Washed nuclei were suspended in 3 volumes of nuclear extraction buffer (NEB) [25 mM HEPES-KOH (pH 7.9), 20\% (v/v) glycerol, $4 \mathrm{mM} \mathrm{MgSO}_{4}, 0.4 \mathrm{mM}$ EGTA, $1 \mathrm{mM} \mathrm{NaF}, 5 \mathrm{mM}$ DTT, $3 \mu \mathrm{g} . \mathrm{mL}^{-1}$ pepstatin $\mathrm{A}$, and $2 \mu \mathrm{g} . \mathrm{mL}^{-1}$ leupeptin]. Ammonium sulfate was added to $0.42 \mathrm{M}$ and then rotated at $2^{\circ} \mathrm{C}$ for $30 \mathrm{~min}$. Nuclear lysate was centrifuged at $200,000 \mathrm{~g}$ for $1 \mathrm{~h}$ and the supernatant was subjected to precipitation of $60 \%$ saturated ammonium sulfate in dialysis buffer (DB) $[20 \mathrm{mM}$ HEPES-KOH (pH 7.9), 20\% (v/v) glycerol, 4 mM MgSO ${ }_{4}, 0.2$ mM EGTA, 0.1 mM EDTA, 2 mM DTT, 0.5 mM PMSF, and 0.5 $\mathrm{mM}$ benzamidine hydrochloride]. The precipitate was dissolved with $2 \mathrm{~mL}$ of $\mathrm{DB}$ and dialyzed twice with MWCO 12,000 cellulose membrane (Wako Chemical USA) at $4^{\circ} \mathrm{C}$ for $1.5 \mathrm{~h}$ each against $500 \mathrm{~mL} \mathrm{DB}$. The resulting nuclear extract was aliquoted and frozen in a deep freezer.

\section{In Vitro Transcription}

In vitro transcription reactions using tobacco nuclear extracts were performed as previously described (Yukawa et al. 1997) with minor modifications. Briefly, reaction was performed in a $20-\mu \mathrm{L}$ volume containing $30 \mathrm{mM}$ HEPES-KOH ( $\mathrm{pH} 7.9), 3$ $\mathrm{mM} \mathrm{MgSO}_{4}, 80 \mathrm{mM}$ KOAc, $0.1 \mathrm{mM}$ EGTA, 2mM DTT, $10 \%$ glycerol, $0.5 \mathrm{mM}$ each of ATP, CTP, UTP, $25 \mu \mathrm{M}$ GTP, $37 \mathrm{kBq}$ $\left[\alpha^{-32} \mathrm{P}\right] \mathrm{GTP}, 0.8 \mathrm{pmol}$ circular plasmids, $0.5 \mu \mathrm{g} \cdot \mathrm{mL}^{-1} \alpha \mathrm{am}-$ anitin, and ca. $15 \mu \mathrm{g}$ tobacco nuclear extract. After inoculation at $28^{\circ} \mathrm{C}$ for the indicated time, the $\alpha^{32}$ P-labeled RNA was extracted by phenolation or Total RNA SafeKit (BIO101). The extracted RNA was separated by $5-8 \%$ polyacrylamide gel containing $7 \mathrm{M}$ urea and TBE. Radioactivity was detected by Bio-Imaging Analyser BAS-2000 II (Fuji Photo Film).

\section{ACKNOWLEDGMENTS}

The authors thank C. White and J.M. Deragon for critical reading of the manuscript. This work was supported by the CNRS and the Université Blaise Pascal. C. Cloix and O. Mathieu are recipients of a fellowship from the Ministère de l'Enseignement supérieur et de la Recherche.

The publication costs of this article were defrayed in part by payment of page charges. This article must therefore be hereby marked "advertisement" in accordance with 18 USC section 1734 solely to indicate this fact.

\section{REFERENCES}

AGI. 2000a. Analysis of the genome sequence of the flowering plant Arabidopsis thaliana. Nature 408: 796-815.

AGI. 2000b. Sequence and analysis of chromosome 3 of the plant Arabidopsis thaliana. Nature 408: 820-822.

AGI. 2000c. Sequence and analysis of chromosome 5 of the plant Arabidopsis thaliana. Nature 408: 823-826.

Agarwal M.L., Aldrich J., Agarwal A., and Cullis C.A. 1992. The flax ribosomal RNA-encoding genes are arranged in tandem at a single locus interspersed by "non-rDNA" sequences. Gene 120: $151-156$.

Appels R., Gerlach W.L., Dennis E.S., Swift H., and Peacock W. J. 1980. Molecular and chromosomal organization of DNA sequences coding for the ribosomal RNAs in cereals. Chromosoma 78: 293-311.

Bachmann L. and Sperlich D. 1993. Gradual evolution of a specific satellite DNA family in Drosophila ambigua, D. tristis and D. obscura. Mol. Biol. Evol. 41: 604-614.

Barciszewska M., Erdmann V.A., and Barciszewski J. 1994. A new type of RNA editing. 5S ribosomal DNA transcripts are edited to mature 5S rRNA. Biochem. Mol. Biol. Int. 34: 437-448.

Baum B.R. and Johnson D.A. 1998. The 5S rRNA gene in sea barley (Hordeum marinum hudson sensu labo): Sequence variation among repeat units and relationship to the $\mathrm{X}$ haplome in barley (hordeum). Genome 41: 652-661.

Blanc G., Barakat A., Guyot R., Cooke R., and Delseny M. 2000. Extensive duplication and reshuffling in the Arabidopsis genome. 
Plant Cell 12: 1093-1101.

Camilleri C., Lafleuriel J., Macadre C., Varoquaux F., Parmentier Y., Picard G., Caboche M., and Bouchez D. 1998. A YAC physical map of Arabidopsis thaliana chromosome 3. Plant J. 14: 633-642. Campell B.R., Soung Y., Posch T.E., Cullis C.A., and Town C.D. 1992. Sequence and organization of 5S ribosomal RNA-encoding genes of Arabidopsis thaliana. Gene 112: 225-228.

Campenhout S.V., Aert R., and Volckaert G. 1998. Orthologous sequence variation among $5 \mathrm{~S}$ ribosomal RNA gene spacer sequences on homoeologous chromosomes 1B, 1D and 1R of wheat and rye. Genome 41: 244-255.

Chen M.W., Anne J., Volckaert G., Huysmans E., Vandenberghe A., and De Wachter R. 1984. The nucleotide sequences of the $5 \mathrm{~S}$ rRNAs of seven molds and a yeast and their use in studying ascomycete phylogeny. Nucl. Ac. Res. 12: 4881-4892.

Cloix C., Tutois S., Mathieu O., Cuvillier C., Espagnol M.C., Picard G., and Tourmente S. 2000. Analysis of 5S rDNA arrays in Arabidopsis thaliana: Physical mapping and chromosome-specific polymorphisms. Genome Research. 10: 679-691.

Creusot F., Fouilloux E., Dron M., Lafleuriel J., Picard G., Billault A., Le Paslier E., Cohen D., Chabouté M.E., Durr A., et al. 1995. The CIC library: A large insert YAC library for genome mapping in Arabidopsis thaliana. The Plant J. 8: 763-770.

Cronn R.C., Zhao X., Paterson A.H., and Wendel J.F 1996. Polymorphism and concerted evolution in a tandemly repeated gene family: 5S ribosomal DNA in diploid and allopolyploid cottons. J. Mol. Evol. 42: 685-705.

Doyle J.J. and Doyle J.L. 1987. A rapid DNA isolation procedure for small quantities of fresh tissue. Phytochem. Bull. 19: 11-15.

Dvorak J., Zhang H.B., Kota R.S., and Lassner M. 1989. Organization and evolution of the $5 \mathrm{~S}$ ribosomal RNA gene family in wheat and related species. Genome 32: 1003-1016.

Ellis T.N., Lee D., Thomas C.M., Simpson P.R., Cleary W.G., Newman M.A., and Burcham K.W.G. 1988. 5S rRNA genes in pisum: Sequence, long range and chromosomal organization. Mol. Gen. Genet. 214: 333-342.

Fan H. and Sugiura M. 1995. A plant basal in vitro system supporting accurate transcription of both RNA polymerase II- and III-dependent genes: Supplement of green leaf component(s) drives accurate transcription of a light-responsive rbcS gene. Embo J. 14: 1024-1031.

. 1996. Basal and activated in vitro transcription in plants by RNA polymerase II and III. Methods Enzymol. 273: 268-277.

Ford P.J. and Brown R.D. 1976. Sequences of 5S ribosomal RNA from Xenopus mulleri and the evolution of $5 \mathrm{~S}$ gene-coding sequences. Cell 8 (4): 485-493.

Ford P.J. and Southern E.M. 1973. Different sequences for 5S RNA in kidney cells and ovaries of Xenopus laevis. Nature New Biol. 241: 7-12.

Fransz P., Armstrong S., Alonso-Blanco C., Fisher T. C., Torres-Ruiz R. A., and Jones G. 1998. Cytogenetics for the model system Arabidopsis thaliana. The Plant J. 13: 867-876.

Franck J.P.C. and Wright J.M. 1993. Conservation of a satellite DNA sequence (SATB) in the tilapiine and haplochromine genome (Pisces: Cichlidae). Genome 36: 187-194.

Fulnecek J., Matyasek R., Kovarik A., and Bezdek M. 1998. Mapping of 5-methylcytosine residues in Nicotiana tabacum 5S rRNA genes by genomic sequencing. Mol. Gen. Genet. 259 (2): 133-141.

Gerlach W.L. and Dyer T.A. 1980. Sequence organization of the repeating units in the nucleus of wheat which contains 5S rRNA genes. Nucl. Ac. Res. 8: 4851-4865.

Grant D., Cregan P., and Shoemaker R.C. 2000. Genomic organization in dicots: Genome duplication in Arabidopsis and synteny between soybean and Arabidopsis. Proc. Natl. Acad. Sci. 97: 4168-4173.

Hariharan P.S., Reddy P.S., and Padayatty J.D. 1987. 5S-rRNA genes in rice embryos. Plant Mol. Biol. 9: 443-451.

Heikkinen E., Launonen V., Muller E., and Bachmann L. 1995. The pvB370 BamHI satellite DNA family of the Drosophila virilis group and its evolutionary relation to mobile dispersed genetic pDv elements. J. Mol. Evol. 41: 604-614.

Heslop-Harrison J.S., Murata M., Ogura Y., Schwarzacher T., and Motoyoshi F. 1999. Polymorphisms and genomic organization of repetitive DNA from centromeric regions of Arabidopsis chromosomes. The Plant Cell 11: 31-42.

Honjo T. and Reeder R.H. 1973. Preferential transcription of Xenopus laevis ribosomal RNA in interspecies hybrids between Xenopus laevis and Xenopus mulleri. J. Mol. Biol. 80: 217-228.

Jarry B. and Rosset R. 1971. Heterogeneity of 5S RNA in Escherichia Coli. Mol. Gen. Genet. 113: 43-50.
Knight E. and Darnell J.E. 1967. Distribution of 5S RNA in HeLa cells. J. Mol. Biol. 28: 491-502.

Komiya H., Shimizu N., Kawakami M., and Takemura S. 1980. Nucleotide sequence of $5 \mathrm{~S}$ ribosomal RNA from Lingula anatina. A study on the molecular evolution of 5S ribosomal RNA from a living fossil. J. Biochem. 88: 1449-1456.

Kotani H., Housouchi T., and Tsuruoka H. 1999. Structural analysis and complete physical mapping of Arabidopsis thaliana chromosome 5 including centromeric and telomeric regions. DNA Research 6: 381-386.

Kowalski S.P., Lan T.H., Feldmann K.A., and Paterson A.H. 1994 Comparative mapping of Arabidopsis thaliana and Brassica oleracea chromosomes reveals islands of conserved organization. Proc. Natl. Acad. Sci. 138: 499-510.

Krol A, Branlant C, Lazar E, Gallinaro H, and Jacob M. 1981. Primary and secondary structures of chicken, rat and man nuclear U4 RNAs. Homologies with U1 and U5 RNAs. Nucl. Ac. Res. 9 (12): 2699-2716

Long E. O. and Dawid I. B. 1980. Repeated genes in eukaryotes. Annu. Rev. Biochem. 49: 727-764.

Lu A., Steege D.A., and Stafford D.W. 1980. Nucleotide sequence of a $5 S$ ribosomal RNA gene in the sea urchin Lytechinus variegatus. Nucl. Ac. Res. 8: 1839-1853.

Madsen C.S., Brooks J.E., De Kloet E., and De Kloet S.R. 1994. Sequence conservation of an avian centromeric repeated DNA component. Genome 37: 351-355

Mestrovic N., Mravinac B., Juan C., Ugarkovic D., and Plohl M. 2000. Comparative study of satellite sequences and phylogeny of five species from the genus Palorus (Insecta, Coleoptera). Genome 43: 776-785.

Morton D.G. and Sprague K.U. 1984. In vitro transcription of a silkworm 5S RNA gene requires an upstream signal. Proc. Natl. Acad. Sci. 81 (17): 5519-5522.

Murata M., Heslop-Harrison J.S., and Motoyoshi F. 1997. Physical mapping of the 5S ribosomal RNA genes in Arabidopsis thaliana by multi-color fluorescence in situ hybridization with cosmid clones. Plant J. 12: 31-37.

Nagata T, Nemoto Y, and Hasezawa S. 1992. Tobacco BY-2 cell line as the "HeLa" cell in the cell biology of higher plants. Int. Rev. Cytol. 132: 1-30.

Nelson D.W., Linning R.M., Davison P.J., and Honda B.M. 1998. 5 '-flanking sequences required for efficient transcription in vitro of 5S RNA genes, in the related nematodes Caenorhabditis elegans and Caenorhabditis briggsae. Gene 218: 9-16.

O'Brien C.A. and Wolin S. 1994. A possible role for the $60-\mathrm{kD}$ Ro autoantigen in a discard pathway for defective 5S rRNA precursors. Genes and Dev. 8: 2891-2903.

Paule M.R. and White R.J. 2000. Survey and summary. Transcription by RNA polymerase I and III. Nucl. Ac. Res. 28 (6): 1283-1298.

Peterson R.C., Doering J.L., and Brown D.D. 1980. Characterization of two Xenopus somatic 5S DNAs and one minor oocyte-specific 5S DNA. Cell 20: 131-141.

Pieler T., Hamm J., and Roeder R. G. 1987. The 5S gene internal control region is composed of three distinct sequence elements, organized as two functional domains with variable spacing. Cell 48: $91-100$.

Pikaard C.S. 1999. Nucleolar dominance and silencing of transcription. Trends in Plant Science. 4: 478-483.

Ro-Choi TS, Reddy R, Henning D, and Busch H. 1971. 5S RNA 3, a new nucleus-specific 5S RNA. Biochem. Biophys. Res. Commun. 44: $963-972$.

Romanova L.Y., Deriagin G.V., Mashkova T.G., Tumeneva I.G., Mushegian A.R., Kisselev L.L., and Alexandrov I.A. 1996. Evidence for selection in evolution of alpha satellite DNA: The central role of CENP-B/Pj $\alpha$ binding region. J. Mol. Biol. 261: $334-340$.

Rogers S.O. and Bendich A.J. 1987. Ribosomal RNA genes in plants: Variability in copy number and in intergenic spacer. Plant Mol. Biol. 9: 509-520.

Sanger F., Nicklen S., and Coulson A.R. 1977. DNA sequencing with chain terminating inhibitors. Proc. Natl. Acad. Sci. 77: 5463-5467.

Schmidt R., West J., Love K., Lenehan Z., Lister C., Thompson H., Bouchez D., and Dean C. 1995. Physical mapping and organization of Arabidopsis thaliana chromosome 4. Science 270: $480-483$.

Schmidt T., Schwarzacher T., and Heslop-Harrison J. S. 1994. Physical mapping of rRNA genes by fluorescent in situ hybridization and structural analysis of 5S rRNA genes and intergenic spacer sequences in sugar beet (Beta vulgaris). Theor. 
Cloix et al.

Appl. Genet. 88: 629-636.

Schneeberger R.G., Creissen G.P., and Cullis C.A. 1989. Chromosomal and molecular analysis of 5S RNA gene organization in the flax, Linum usitatissinum. Gene 83: 75-84.

Selker E.U., Stevens J.N., and Metznberg R.L. 1985. Heterogeneity of 5S RNA in fungal ribosomes. Science 277: 1340-1342.

Sharp S.J. and Garcia A.D. 1988. Transcription of the Drosophila melanogaster 5S RNA gene requires an upstream promoter and four intragenic sequence elements. Mol. Cell. Biol. 8 (3): 1266-1274.

Shi H., O'Brien C.A., Van Horn D.J., and Wolin S.L. 1996. A misfolded form of 5S rRNA is complexed with the Ro and La autoantigens. RNA 2: 769-784.

Trontin J.F., Grandemange C., and Favre J.M. 1999. Two highly divergent 5S rDNA unit size classes occur in composite tandem array in European larch (Larix decidua Mill.) and Japanese larch (Larix kaempferi(Lamb.) Carr.). Genome 42: 837-848.

Tutois S., Cloix C., Cuvillier C., Espagnol M.C., Lafleuriel J., Picard G., and Tourmente S. 1999. Structural analysis and physical mapping of a pericentromeric region of chromosome 5 of Arabidopsis thaliana. Chromosome Research 6: 1-14.

Tyler B.M. 1987. Transcription of Neurospora crassa 5S rRNA enes requires a TATA box and three internal elements. J. Mol. Biol. 196 (4): 801-811.

Venkateswarlu K., Lee S. W., and Nazar R. N. 1991. Conserved upstream sequence elements in plant $5 \mathrm{~S}$ ribosomal RNA-encoding genes. Gene 105: 249-253.

Vershinin A.V., Alkhimova E.G., and Heslop-Harrison J.S. 1996. Molecular diversification of tandemly organised DNA sequences and heterochromatic chromosome regions in some Triticeae species. Chromosome Res. 4: 517-525.

Vian A., Henry-Vian C., Ledoigt G., Baillaud L., and Desbiez M.O. 1993. Circadian variations of polysome assembly in the hypocotyl of Bidens pilosa. Plant Physiol. Biochem. 31 (5): 675-681.

Wallace H. and Langridge W. H. R. 1971. Differential amphiplasty and the control of ribosomal RNA synthesis. Heredity 27: 1-13.

Wildeman A.G. and Nazar R.N. 1982. Structural studies of $5 \mathrm{~S}$ ribosomal RNAs from a thermophilic fungus, Thermomyces lanuginosus. A comparison of generalized models for eukaryotic 5 S RNAs J. Biol. Chem. 257 (19): 11395-11404.

Wolfe K.H. and Shields D.C. 1997. Molecular evidence for an ancient duplication of the entire yeast genome. Nature 387: 708-713.

Yukawa Y, Sugita M., and Sugiura M. 1997. Efficient in vitro transcription of plant tRNA Ser genes in a nuclear extract from tobacco cultured cells. Plant J. 12 (4): 965-970.

Yukawa Y., Sugita M., Choisne N., Small I., and Sugiura M. 2000. The TATA motif, the CAA motif and the poly (T) transcription termination motif are all important for transcription reinitiation on plant tRNA genes. Plant J. 22: 439-447.

Wolffe A.P. 1989. Dominant and specific repression of Xenopus oocyte 5S RNA genes and satellite I DNA by Histone H1. Embo J. 8: $527-537$.

Received January 23, 2001; accepted in revised form October 26, 2001.

\section{Genome Research}




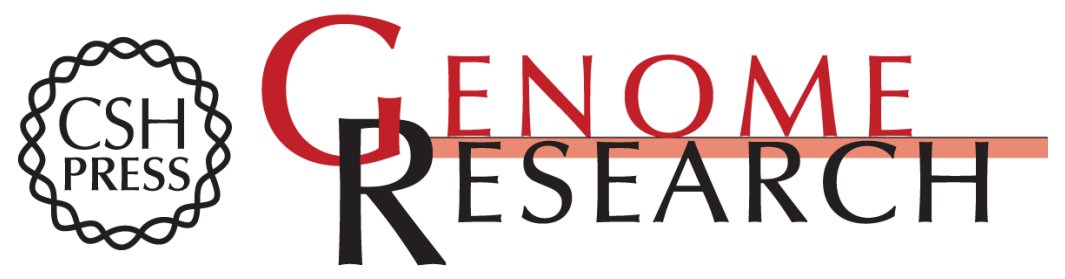

\section{Analysis of the 5S RNA Pool in Arabidopsis thaliana: RNAs Are Heterogeneous and Only Two of the Genomic 5S Loci Produce Mature 5S RNA}

Catherine Cloix, Sylvie Tutois, Yasushi Yukawa, et al.

Genome Res. 2002 12: 132-144

Access the most recent version at doi:10.1101/gr.181301

\section{License}

Email Alerting

Receive free email alerts when new articles cite this article - sign up in the box at the Service top right corner of the article or click here.

\section{Affordable, Accurate Sequencing.}

